\title{
EFFECT OF FEEDING ON RAW, SOAKED AND GERMINATED FENUGREEK FLOUR ON BLOOD SUGAR AND LIPIDS PROFILE IN DIABETIC RATS
}

\author{
Salem. M. A. M.
}

Dept. Food Sci. \& Tech. Fac. Agric., Tanta Univ.

\begin{abstract}
The present study was designed to investigate the effect of feeding on diet containing $5 \%$ of raw fenugreek flour (RFF) and soaked fenugreek flour (SFF) or $5 \%$ and $10 \%$ of germinated fenugreek flour (GFF) on the blood glucose level, lipid profile and serum transaminase enzymes, as well as, body weight, food intake, food efficiency ratio (FER) and some organs weight in streptozotocin-induced diabetic rats. The obtained results could be summarized as follows:

The supplementation of basal diet with fenugreek flour led to significant increase of final body weight, body weight gain (\%), food intake, FER and organs weight of diabetic rats specially with 5 and $10 \%$ of GFF, while relative organs weight were decreased with $5 \%$ of SFF or $5 \%$ and $10 \%$ GFF compared with that recorded of diabetic control. In relation to blood glucose level, the addition of RFF to the basal diet reduced blood glucose level of diabetic rats but still in the range of diabetic > $248.4 \mathrm{mg} / \mathrm{dl}$, while supplementation of basal diet with SFF resulted to a decrease in blood glucose level $(231.9 \mathrm{mg} / \mathrm{dl})$ but still near from the range of diabetic. On the other hand, GFF at two levels (5 and 10\%) caused to more reduction of blood glucose level of diabetic rats, and the more effect was observed with $10 \%$ GFF $(209.6 \mathrm{mg} / \mathrm{dl})$. Streptozotocin-induced diabetic rats had a higher level of total cholesterol (TC), low density lipoprotein- cholesterol (LDL-C) and total cholesterol/high density lipoproteincholesterol (TC/HDL-C) and lower level of HDL-C comparing with normal rats. The addition of fenugreek seeds flour in all forms to basal diet improved the previous parameters and they became in the normal range (TC, 110.86-143.45; LDL-C, 47.1093.47; TC/HDL-C, 1.74-2.87 and HDL-C, 49.89-63.76 mg/dl). The feeding of diabetic rats on diet containing $5 \%$ or $10 \%$ GFF decreased the liver content of total lipids, phospholipids, cholesterol and triglycerides (TG) to the level, where no significant difference was noticed with normal control. Also, the results revealed that, fecal output, fecal lipid and fecal cholesterol excretion were increased with supplementation of basal diet with raw, soaked or germinated fenugreek flour. This supplementation improved serum transaminase enzymes especially alanine-aminotransferase enzyme (AST). So, it can be recommended that, using fenugreek flour especially germinated fenugreek flour at the level of $10 \%$ had a pronounced effect in reducing blood glucose and cholesterol levels.
\end{abstract}

Keywords:Fenugreek, blood sugar, hypocholesterolemic, germination lipid profile.

\section{INTRODUCTION}

Diabetes mellitus is a chronic disorder of glucose intolerance. It is characterized by high blood glucose level and glucosuria from dysfunction of pancreatic cells and insulin resistance. The defective cells results in lack of total or partial synthesis of insulin. The resistance is caused by cell membrane where glucose is not transported to the cells for oxidation. As glucose is not metabolized, high amount of glucose is circulating in the blood (hyperglycemia). To keep the normal level of glucose in the blood, the kidney 
removes the extra sugar from the blood and excretes it in the urine (glycosuria). Because glucose is not utilized by the body cells, the body is under constant impression of hunger and that is why diabetics feel increased appetite (polyphagia) and eat more frequently (Robinson et al., 1986 and Safdar et al., 2006).

In spite of the fact that insulin has become one of the most important therapeutic agents known to medicine, research workers again have been making efforts to find insulin substitutes from synthetic or plant sources for the treatment of diabetes. Many of them have remained as an alternative to conventional therapy in depressed areas where insulin is not readily available, (Sanehez et al., 1994).

Hypercholesterolemia remains a major risk factor for cardiovascular disease, with approximately one third of the many industrialized populations having blood cholesterol levels equal to or higher than $240 \mathrm{mg} / \mathrm{dL}$, thus placing them in the high risk category for cardiovasuclar disease (Nicolosi \& Ockene, 1996).

Many traditional plants treatments for diabetes are used through the world. Plant drugs and herbal formulation are frequently considered to be less toxic and more free from side effects than synthetic ones (Bialey \& Day, 1989; Bhattacharya et al., 1997 and Pari \& Saravanan, 2004). Based on the World Health Organization recommendation, hyperglycaemic agents of plant origin used in traditional medicine are important (WHO, 1980). Fenugreek is an annual legume plant, native to the Mediterranean region, but from ancient times, it has also been grown in the near and Middle East, now fenugreek is grown all over the world. The seed contain many nutrients including protein, carbohydrtes, fats, vitamins and minerals as well as enzymes. The seeds also contain alkaloids (mainly trigonelline), steroidal saponins, galactomannan polysaccharide and mucilaginous fiber are thought to account for many of the beneficial effect of fenugreek. The steroidal saponins are thought to inhibit cholesterol absorption and synthesis, while the fiber may lower blood sugar levels (Ribes et al., 1986; Sauvaire et al., 1991; Raghuram et al., 1994; Kochhar \& Nagi, 2005 and Mathur \& Mathur, 2006).

Raw fenugreek seeds has been used to regulate blood sugar in healthy, obese, as well as non insulin dependent or the type-2 diabetic persons. Fenugreek incorporated in the experimental diet of human subjects has been shown to reduce serum cholesterol, LDL-C, very low density lipoprotein cholesterol (VLDL-C) and TG level which are an independent risk factor for cardiovascular disease. The seeds also are reported to produce a significant reduction in LDL-C and VLDLC fractions without altering the HDL$\mathrm{C}$ fraction. However, its use as a dietary adjunct is limited because of its bitterness (Saibaba and Raghuram, 1997).

Earlier studies reported that, sprouting or soaking removes the bitterness to a certain extent and make it possible to use in increased quantities for incorporation into various preparations which are commonly consumed. The beneficial effects of germinated fenugreek and its use at different levels in reducing blood cholesterol level in human subjected are firmly established (Sharma, 1986; Madar et al., 1988; Sharma \& Raghuram, 
1990; Sharma et al., 1990; Neeraja \& Rajyalakshmi, 1996; Saibaba \& Raghuram, 1997 and Sowmya \& Rajyalakshmi, 1999). Control of diabetes by spices and other natural products is becoming popular and is more appropriate and economical for use in developing countries (Safadar et al., 2006). The effect of legumes on blood sugar and cholesterol were studied by many researchers e.g. Panlasigui et al. (1995) who found that, blood sugar response to all legumes was significantly lower compared with bread, they also recommended that, legumes could be added to the list of foods for diabetics and hyperlipidaemics and continuous consumption in larger amounts.

Previous study of Abd El-Hady et al., (2006) proved that, supplementation of wheat flour with $5 \%$ of raw and soaked fenugreek seed flours as well as $5 \%$ and $10 \%$ of germinated fenugreek seed flour gave a good organoleptic properties and overall acceptability of balady bread compared with the control (100\% wheat flour). The present investigation was undertaken to study the effect of raw, soaked and germinated fenugreek flour on changes in blood sugar level; some organ weight, serum and liver lipid parameters of diabetic rats.

\section{MATERIALS AND METHODS}

\section{Materials:}

Fenugreek (Trigonella foenum graecum) seeds variety "Giza 80" were obtained from Agriculture Research Center, Giza , Egypt.

Male albino rats were purchased from Faculty of Science, Tanta University, Egypt.

\section{Preparation of samples:}

Fenugreek seeds were first cleaned and freed from broken seeds, dust and other foreign materials and divided into three portions. One portion was left unprocessed and called raw fenugreek seed (RFS). The second portion of seeds was soaked in tap water for 12 hours at room temperature $25^{\circ} \mathrm{C} \pm 2^{\circ} \mathrm{C}$ using seed to water ratio of $1: 5(\mathrm{w} / \mathrm{v})$. The soaked seeds were rinsed in distilled water and then dried at $55-65^{\circ} \mathrm{C}$ and referred to as soaked fenugreek seeds (SFS). The third portion of seeds was soaked as described before, after soaking, seeds were transferred to moistened cotton layers, and allowed to germinate in the dark at room temperature for four days, during germination the cotton layers were kept always moist. After germination process the germinated fenugreek seeds were dried at $55-65^{\circ} \mathrm{C}$ and referred as germinated fenugreek flour (GFF). The dried samples of raw, soaked and germinated seeds were ground up to pass through 100 mesh screen sieve and powdered samples were kept in plastic containers at $-20^{\circ} \mathrm{C}$ until used.

\section{Biological evaluation:}

Fenugreek seeds flour (raw, soaked, or germinated) were evaluated nutritionally to figure out their effect in lowering the level of blood glucose as well as different lipid parameters in diabetic cases, through animal feeding study. 
Salem. M. A. M.

Experimental diets:

Table (A) shows the composition of experimental diets.

Table (A):Composition of experimental diets ( $\mathrm{g} / \mathrm{kg}$ diet) as reported by Kim and Shin (1998).

\begin{tabular}{|l|c|c|c|c|c|}
\hline \multicolumn{1}{|c|}{ Constituents } & \multicolumn{5}{|c|}{ No. of diets recipes } \\
\cline { 2 - 6 } & $\mathbf{1}^{\boldsymbol{*}}$ & $\mathbf{2}$ & $\mathbf{3}$ & $\mathbf{4}$ & $\mathbf{5}$ \\
\hline Casein & 200 & 200 & 200 & 200 & 200 \\
Wheat starch & 698 & 648 & 648 & 648 & 598 \\
Corn oil & 50 & 50 & 50 & 50 & 50 \\
Mineral mixture & 35 & 35 & 35 & 35 & 35 \\
Vitamins mixture & 10 & 10 & 10 & 10 & 10 \\
DL-Methionine & 3 & 3 & 3 & 3 & 3 \\
Choline bitartarate & 2 & 2 & 2 & 2 & 2 \\
Cholesterol & 2 & 2 & 2 & 2 & 2 \\
Raw fenugreek flour & 0 & 50 & 0 & 0 & 0 \\
Soaked fenugreek flour & 0 & 0 & 50 & 0 & 0 \\
Germinated fenugreek flour & 0 & 0 & 0 & 50 & 100 \\
\hline
\end{tabular}

${ }^{*}$ Diet No. 1 was a control diet (basal diet) given to both normal and diabetic control rats.

Diet No. 2: Basal diet supplemented with $5 \%$ raw fenugreek flour.

Diet No. 3: Basal diet supplemented with $5 \%$ soaked fenugreek flour.

Diet No. 4: Basal diet supplemented with $5 \%$ germinated fenugreek flour.

Diet No. 5: Basal diet supplemented with $10 \%$ germinated fenugreek flour.

\section{Animals:}

The experimental animals used in this study were male healthy albino rats (30 rats), weight ranging between $60-70 \mathrm{gm}$. The rats were housed individually in a wire bottomed, stainless steel cage, under normal healthy laboratory conditions. The experimental animals were fed on basal diet for one week. Diet and water were supplied ad-libitum throughout the experimental period of 6 weeks.

\section{Experimental design and induction of diabetic rats:}

After acclimation, rats were randomly divided into two groups. The first group (5 rats) was kept as normal control, and fed on basal diet. The second group (25 rats) were injected with streptozotocin (dissolved in $0.1 \mathrm{M}$ citric acid buffer and adjusted at $\mathrm{pH} 4.5)$ into the leg muscle $(50 \mathrm{mg} / \mathrm{kg}$ body weight) after 12 hours fasting, to induce hyperglycemia according to Lutz and Pardrige (1993). After two days of the injection with streptozotocin, blood glucose concentration was determined. Animals having blood glucose concentration over $248.4 \mathrm{mg} / \mathrm{dl}$ were considered diabetes as reported by Esmerino (1998). After ensuring that rats became diabetic, diabetic rats were divided into five subgroups (5 rats each). First subgroup was left as diabetic control and fed on basal diet. The other subgroups (second, third, fourth and fifth subgroups) were fed on basal diet supplemented with $5 \%$ raw, $5 \%$ soaked, $5 \%$ and $10 \%$ germinated fenugreek flour, respectively during the whole experiment (6 weeks). All rats were weighed weekly as for as food intake. Feces were collected in polyethylene packages and stored at $\left(-20^{\circ} \mathrm{C}\right)$ until analysis. At the end of the experiment weight gain and food efficiency 
ratio (FER) were calculated for each group of rats (calculated as gram of weight gain per gram of food intake $\times 100$ ).

\section{Blood sampling:}

In all the previously mentioned groups blood samples were taken at the end of the experiment. The blood collected from vein plexus eye after 12 hours fasting were put in dry clean centrifuge tubes and left to clot. The blood was centrifuged for ten minutes at $3000 \mathrm{xg}$ to separate the serum, which was carefully aspirated and transferred into clean plastic tubes and kept frozen at $-20^{\circ} \mathrm{C}$ until analyzed (El-Khamissy, 2005).

\section{Collection of the organs:}

All rats were sacrificed and the organs (liver, kidney, heart and spleen) were separated by careful dissection, cleaned from the adhesive matter and washed in saline solution, then weighed. The relative weight of the organs were calculated following the next equation:

Relative organ weight = Organ weight / Final body weight X 100

\section{Determination of blood glucose:}

Blood glucose was measured according to the method described by Alles et al., (1999) using blood glucose meter (Free Style TM). A drop of blood was placed on a test strip and blood glucose was measured immediately with a blood glucose meter.

\section{Determination of serum lipids:}

The concentration of total cholesterol (TC), HDL-C and TG in the serum were determined without extraction by using enzymatic colorimetric method with commercial available kits (cholesterol, kit \#276-64909; highdensity lipoprotein, kit \# 278-67409 and triglyceride, kit \# 274-69807; Wake Chemical, Osaka, Japan). Kim and Shin (1998) procedures were employed to perform the previous mentioned determinations. Low-density lipoprotein cholesterol concentration was calculated by the difference between TC and HDL-C according to the method of Kim and Shin (1998).

Determination of liver cholesterol, liver triglycerides and fecal cholesterol:

Liver cholesterol, liver triglyceride and fecal cholesterol concentrations were determined according to Kim and Shin (1998) method using the previously mentioned kits. Liver and fecal samples were extracted with solvent before subjecting to the aforementioned analysis according to the method of Folch et al., (1957). A solvent system composed of chloroform: methanol, 2: $1(\mathrm{v} / \mathrm{v})$ was used.

\section{Determination of total lipids:}

Total lipids content of liver and feces were determined by the method of Folch et al. (1957).

\section{Determination of liver phospholipids:}

Liver phospholipids were extracted by solvents according to the method of Folch et al. (1957). The concentration of liver phospholipids were determined by enzymatic colorimetric method using kit \# 996-54001, wake Chemical, Osaka, Japan. 


\section{Serum transaminase activities:}

Alanine aminotransferase (ALT) and aspertate amino transferase (AST) activities were determined colorimetrically according to the method described by Reitman and Frankel (1957). The activities of ALT and AST were calculated and expressed as international units (I.U) by using special Table provided with kits. Colorimetric determinations of ALT and AST activities were measured using $\alpha$-ketoglutarate in a phosphate buffer-alanine solution (GPT substrate) and $\alpha$-keotglutarate in a phosphate buffer-aspertate solution (GOT substrate), respectively according to two reactions.

Alanine $+\alpha$-keotglutatarate $\stackrel{\mathrm{GPT}}{\longleftrightarrow}$ pyruvate + glutamate

Aspertate $+\alpha$-ketoglutarate $\stackrel{\text { GOT }}{\longleftrightarrow}$ Oxaloacetate + glutamate

The pyruvate and oxalaoacetae formed were colorimetrically measured in its derivative form 2, 4 dinitrophenylhydrasone, at wave length $546 \mathrm{~nm}$.

Statistical analysis:

Most of the received data were analyzed statistically using the analysis of variance and the means were further tested using the least significant difference test (L.S.ýD) as outline by Steel and Torrie (1980).

\section{RESULTS AND DISCUSSION}

Effect of raw, soaked and germinated fenugreek flour on body weight, body weight gain (\%) food intake and food efficiency ratio of diabetic rats:

Table (1) summarize the mean values of initial body weight, final body weight, body weight gain, food intake and food efficiency ratio of all groups. The mean values of initial body weight of all groups after one week of acclimatization feeding on basal diet, were nearly the same and with non significant difference. The mean values ranged from 67.33 to $69.86 \mathrm{~g}$. At the end of experimental feeding ( 6 weeks) the final body weight of the control diabetic rats (fed on basal diet without any addition) was significantly lower than non diabetic group ( normal control). The mean values of final body weight for other diabetic groups fed on basal diet supplemented with $5 \%$ raw or soaked fenugreek flour or 5 and $10 \%$ germinated fenugreek flour were higher compared with control diabetic group, but still less than normal group. The results in Table (1) also indicated that, diabetic rats fed on a diet containing raw, soaked or germinated fenugreek flour had a greater body weight gain, food intake and FER than those of diabetic control. On the other hand, they were high significantly less than that of the normal group, where the body weight gain was negative in the diabetic control group $(-11.53 \mathrm{~g})$ compared with that of normal control group $(38.57 \mathrm{~g})$. The results also revealed that, supplementation of basal diet with raw, soaked or germinated fenugreek flour led to increase in final body weight, body weight gain, food intake and FER of diabetic rats especially with $10 \%$ germinated fenugreek 
flour. This may be to the improvement in their health due to the effect of lowering the blood glucose and helped the rats to overcome the impaired body function and recovered the appetite to food and gain in weight (Gabr, 1998). The results are in agreement with those which observed by SayedAhmed (2002), who reported that fenugreek protein gave high gain compared to the positive control.

Table (1): Effect of raw, soaked and germinated fenugreek flour on body weight, body weight gain, food intake and food efficiency ratio of diabetic rats.

\begin{tabular}{|c|c|c|c|c|c|c|}
\hline \multirow[b]{2}{*}{ Dietary groups } & \multirow{2}{*}{$\begin{array}{l}\text { Initial } \\
\text { body } \\
\text { weight } \\
\text { (g) }\end{array}$} & \multirow{2}{*}{$\begin{array}{l}\text { Final } \\
\text { body } \\
\text { weight } \\
\text { (g) }\end{array}$} & \multicolumn{2}{|c|}{ Body weight gain } & \multirow{2}{*}{$\begin{array}{c}\text { Food } \\
\text { intake } \\
(g)\end{array}$} & \multirow{2}{*}{$\begin{array}{c}\text { Food } \\
\text { efficiency } \\
\text { ratio (FER) } \\
\star \star \star\end{array}$} \\
\hline & & & g & $\%$ * & & \\
\hline Normal control & $67.40 \mathrm{a}$ & $105.97 \mathrm{e}$ & $38.57 \mathrm{~d}$ & 57.23 & $290.51 \mathrm{c}$ & $13.28 \mathrm{c}$ \\
\hline Diabetic control & $69.86 \mathrm{a}$ & $58.33 \mathrm{a}$ & -11.53 & -16.50 & $212.61 \mathrm{a}$ & -5.42 \\
\hline Group 3 & $68.49 \mathrm{a}$ & $81.35 b$ & $12.86 \mathrm{a}$ & 18.78 & $264.18 b$ & $4.86 \mathrm{a}$ \\
\hline Group 4 & $69.24 \mathrm{a}$ & $87.18 \mathrm{c}$ & $17.94 \mathrm{~b}$ & 25.91 & $268.11 \mathrm{bc}$ & $6.69 \mathrm{~b}$ \\
\hline Group 5 & $67.33 \mathrm{a}$ & $86.81 \mathrm{c}$ & $19.48 \mathrm{bc}$ & 28.93 & 268.62 bc & $7.25 b$ \\
\hline Group 6 & $68.78 \mathrm{a}$ & $91.45 \mathrm{~d}$ & $22.67 \mathrm{c}$ & 32.96 & $288.15 \mathrm{bc}$ & $7.87 \mathrm{~b}$ \\
\hline
\end{tabular}

* Body weight gain (\%) = Final body weight-initial body weight/initial body weight x 100

${ }^{\star \star}$ Food Efficiency ratio = Body weight gain/Food intake $\times 100$

Each value was an average of five determinations.

Values followed by the same letter in column are not significantly different at $P \leq 0.05$.

Normal control (non diabetic control) normal rats fed on basal diet.

Diabetic control , diabetic rats fed on basal diet.

Group 3, diabetic rats fed on basal diet supplemented with 5\% RFF.

Group 4, diabetic rats fed on basal diet supplemented with $5 \%$ SFF.

Group 5, diabetic rats fed on basal diet supplemented with $5 \%$ GFF.

Group 6, diabetic rats fed on basal diet supplemented with $10 \%$ GFF.

Effect of raw, soaked and germinated fenugreek flour on the organs and relative organs weight of diabetic rats:

Liver, kidney, heart and spleen of rats fed on basal diet and other treatments, as well, were weighed at the end of experimental period (6 weeks) and the ratio of each organ to final body weight of rats was calculated. The results are present in Table (2).

As shown in Table (2) non diabetic rats fed on normal diet (diet 1) had a higher liver weight comparing with diabetic rats (diabetic control) and all rats fed on basal diet supplemented with fenugreek flour either raw, soaked or germinated. A smaller liver in diabetic rats (diabetic control) than the liver of rats of other groups, was presumably related to the lower body weight. These results are in agreement with that published by Abd El-Lateef \& Salem (1996). As for liver, kidney, heart and spleen weight had the same trend. David et al. (1997) pointed to the effect of diabetic mellitus on some organs e.g. kidney, retaina and nervous systems. The results in Table (2) also revealed that, the differences between kidney and heart weight of the normal rats and diabetic rats fed on supplemented diet with raw, soaked or germinated fenugreek flour were not significant, but the diet supplemented 
Salem. M. A. M.

with $10 \%$ germinated fenugreek flour gave the best and nearest results comparing with normal rats fed on basal diet.

Table (2):Organs weight (liver, kidney, heat and spleen) and relative organs weight* of normal and diabetic rats fed on different experimental diets for 6 weeks.

\begin{tabular}{|c|c|c|c|c|c|c|c|c|c|}
\hline \multirow{2}{*}{$\begin{array}{c}\text { Dietary } \\
\text { groups }\end{array}$} & $\begin{array}{c}\text { Final } \\
\text { body } \\
\text { weight }\end{array}$ & \multicolumn{2}{|c|}{ Liver } & \multicolumn{2}{|c|}{ Kidney } & \multicolumn{2}{|c|}{ Heart } & \multicolumn{2}{c|}{ Spleen } \\
\cline { 3 - 10 } & gm & $\begin{array}{c}\text { R.O.W.* } \\
\%\end{array}$ & gm & $\begin{array}{c}\text { R.O.W* } \\
\%\end{array}$ & gm & $\begin{array}{c}\text { R.O.W } \\
\%\end{array}$ & gm & $\begin{array}{c}\text { R.O.W } \\
\%\end{array}$ \\
\hline Normal control & $105.97 \mathrm{e}$ & 4.86 & 4.59 & $1.02 \mathrm{~b}$ & 1.02 & $0.39 \mathrm{ab}$ & 0.37 & $0.28 \mathrm{c}$ & 0.26 \\
Diabetic control & $58.33 \mathrm{a}$ & 3.38 & 5.79 & $0.74 \mathrm{a}$ & 1.27 & $0.34 \mathrm{a}$ & 0.58 & $0.19 \mathrm{a}$ & 0.33 \\
Group 3 & $81.35 \mathrm{~b}$ & 3.69 & 4.54 & $0.83 \mathrm{a}$ & 1.02 & $0.35 \mathrm{ab}$ & 0.43 & $0.23 \mathrm{~b}$ & 0.28 \\
Group 4 & $87.18 \mathrm{c}$ & 3.25 & 3.73 & $0.85 \mathrm{a}$ & 0.97 & $0.37 \mathrm{ab}$ & 0.42 & $0.22 \mathrm{~b}$ & 0.25 \\
Group 5 & $86.81 \mathrm{c}$ & 3.77 & 4.34 & $0.87 \mathrm{ab}$ & 1.00 & $0.40 \mathrm{~b}$ & 0.46 & $0.25 \mathrm{~b}$ & 0.29 \\
Group 6 & $91.45 \mathrm{~d}$ & 3.86 & 4.22 & $0.89 \mathrm{ab}$ & 0.97 & $0.38 \mathrm{ab}$ & 0.42 & $0.24 \mathrm{~b}$ & 0.26 \\
\hline
\end{tabular}

Each value was an average of five determinations.

Values followed by the same letter in column are not significantly different at $P \leq 0.05$

* Relative organ weight (R.O.W.) = Organ weight / Final body weight $x 100$

Normal control, Diabetic control, group 3 ... etc. as in Table 1.

In relation to, the percentage of organs to body weight, the results in Table (2) indicated that, the mean value of liver weight to body weight ratio of diabetic rats fed on basal diet $(5.79 \%)$ showed a noticeable increasing compared to those fed on basal diet (normal group 4.59\%) and fed on a diets supplemented with raw, soaked and two germinated fenugreek flour, 4.54, $3.73,4.34$ and $4.22 \%$, respectively. The mean values of kidney, heart and spleen weights to body weight ratio gave the same results and trend. This may be due to the hepatocytic degeneration, necrosis, pathological and physiological disturbance (Lehninger et al., 1993).

Effect of raw, soaked and germinated fenugreek flour on blood glucose level of diabetic rats:

Diabetic mellitus is one of the most serious diseases that important in the last years. In fact, it is one of the common causes of death in Egypt. The number of diabetic people has been increasing from year to another. The folk medicine in Egypt has described twenty five kinds of Egyptian herbs and plants including fenugreek prescriptions to be concerned with the treatment of diabetes mellitus (Jansen et al., 1990 and Eskander \& Jun, 1995).

Data in Table (3) represent the mean values of blood glucose levels of non diabetic (normal) and the experimentally diabetic rats fed on basal diet alone or basal diet supplemented with one type of fenugreek flour.

Table (3): Blood glucose level of normal and diabetic rats fed on different experimental diets for 6 weeks.

\begin{tabular}{|c|c|c|c|c|c|c|c|c|}
\hline \multirow{2}{*}{$\begin{array}{l}\text { Dietary } \\
\text { groups }\end{array}$} & \multirow{2}{*}{$\begin{array}{c}\text { Before } \\
\text { treat. }\end{array}$} & \multirow{2}{*}{$\begin{array}{c}\text { After } 4 \\
\text { days of } \\
\text { streptoz- } \\
\text { otocin } \\
\text { injectjon }\end{array}$} & \multicolumn{6}{|c|}{ Blood glucose levels changes every week (mg/dL) } \\
\hline & & & $1^{\text {st }}$ & $2^{\text {nd }}$ & $3^{\text {rd }}$ & $4^{\text {th }}$ & $5^{\text {th }}$ & $6^{\text {th }}$ \\
\hline Nor & & $81.70 \mathrm{a}$ & 98.7 & & & & & 102. \\
\hline & 81.6 & $356.00 \mathrm{~b}$ & 364.2 & & $2 \mathrm{e}$ & & & $4 \mathrm{~d}$ \\
\hline Group 3 & $82.41 \mathrm{a}$ & $354.55 \mathrm{~b}$ & $349.80 \mathrm{c}$ & $338.62 \mathrm{~d}$ & $306.11 \mathrm{~d}$ & $287.05 \mathrm{~d}$ & $274.20 \mathrm{~d}$ & $259.71 \mathrm{c}$ \\
\hline Group 4 & $87.11 \mathrm{a}$ & $335.70 \mathrm{~b}$ & $311.09 \mathrm{~b}$ & $296.74 \mathrm{c}$ & $280.04 \mathrm{c}$ & $258.64 \mathrm{c}$ & 241.04 bc & $231.93 b$ \\
\hline Group 5 & $90.13 a$ & $339.49 \mathrm{~b}$ & $313.19 \mathrm{~b}$ & $291.16 \mathrm{c}$ & $274.49 \mathrm{c}$ & $255.93 \mathrm{c}$ & $247.15 \mathrm{c}$ & $227.94 \mathrm{~b}$ \\
\hline Group 6 & $93.54 \mathrm{a}$ & $348.73 b$ & $307.23 \mathrm{~b}$ & $253.10 \mathrm{~b}$ & $237.41 \mathrm{~b}$ & $230.56 \mathrm{~b}$ & $218.08 b$ & $209.60 \mathrm{~b}$ \\
\hline
\end{tabular}

Each value was an average of five determinations. 
Values followed by the same letter in column are not significantly different at $P \leq 0.05$ Normal control, Diabetic control, group 3 ... etc. as in Table 1.

One week before experiment (acclimatization period), when all rats were fed on basal diet, the mean values of fasting blood glucose levels were nearly the same in all groups and ranged between 79.51 and $93.54 \mathrm{mg} / \mathrm{dl}$.

After inducing diabetes by streptozotocin injection in all experimental groups except the normal control (non diabetic group) and starting feeding by basal diet for normal group and diabetic group, as well as, basal diet supplemented with raw, soaked and germinated fenugreek flour for other diabetic groups, after four days of streptozotocin injection marked increase occurred and glucose level ranged between 335.70 and $356.0 \mathrm{mg} / \mathrm{dL}$. Meanwhile, the mean blood glucose level of non diabetic control group remained normal. Data in Table (3) also indicated that, there was no significant differences in blood glucose levels for diabetic rats (diabetic control ); these mean values of blood glucose level nearly remain the same until the end of experiment. With regard to using $5 \%$ raw, $5 \%$ soaked, $5 \%$ or $10 \%$ germinated fenugreek flour in the diets of diabetic groups, the mean blood glucose levels gradually decreased from the second week of feeding, but still significantly as compared with diabetic group (diabetic control), although the mean values still significantly higher than non diabetic control. The reduction was increased with prolonging the feeding period. Apparent also from Table (3) that, GFF had more effect on blood glucose level than raw or soaked fenugreek flour. The lowest effect was noticed with RFF, the rats fed on it were still in the range of diabetic $>248.4 \mathrm{mg} / \mathrm{dl}$. The obtained data concerned with blood glucose levels indicate that, the supplementation of diet with $10 \%$ GFF gave the best results followed by 5\% GFF then $5 \%$ SFF.

Aforementioned results are in a good agreement with those found by many authors, Madar et al., (1988) reported that, addition of powdered fenugreek seed soaked in water significantly reduced subsequent postprandial glucose level and had a potential benefit in the treatment of non insulin dependent diabetics. Sharma et al., (1990) studied the effect of fenugreek seed on blood glucose in diabetic patient and found that, fenugreek seeds reduced blood glucose level and useful in management of diabetes. Also, Raghuram et al., (1994) stated that, fenugreek has been shown to reduce fasting and postprandial blood glucose levels in diabetic patients, as well as, fenugreek in the diet significantly reduced the area under the plasma glucose curve, half life and increased the metabolic clearance rate. In addition, it increased erythrocyte insulin receptors. Thus, fenugreek may exert it hypoglycaemic effect by acting at the insulin receptors as well as, at the gastrointestinal level. Kochhar and Nagi (2005) studied the effect of fenugreek and bittergourd seeds either raw or cooked on diabetic patients. They concluded that, a significant reduced the fasting and postprandial glucose levels of diabetic patients, and the mixture can be successfully used for lowering blood glucose in diabetics. 
Effect of raw, soaked and germinated fenugreek flour on some serum lipid parameters of diabetic rats:

The relationship between lipids abnormalities and diabetes is complex, there is usually a specific lipid abnormality found in diabetes (Rosalyn and Bauman, 1983). It was reported that hypertriglyceridemia, hypercholesterolemia and reduced HDL-C level were commonly seen in diabetes. Blood samples were collected from rats after six weeks of dietary treatment, for analysis of serum total cholesterol, lipoprotein cholesterol (LDL$\mathrm{C} \& \mathrm{HDL}-\mathrm{C}$ ) and TG concentration, and the results are given in Table (4).

Table (4): Serum lipoprotein profile and triglycerides concentration in normal and diabetic rats fed on different experimental diets.

\begin{tabular}{|c|c|c|c|c|c|c|c|}
\hline $\begin{array}{c}\text { Dietary } \\
\text { groups }\end{array}$ & $\begin{array}{c}\text { Total } \\
\text { cholesterol } \\
\mathbf{m g} / \mathbf{d l}\end{array}$ & $\begin{array}{c}\text { HDL-C } \\
\mathbf{m g} / \mathbf{d l}\end{array}$ & $\begin{array}{c}\text { LDL- C } \\
\mathbf{m g} / \mathbf{d l}\end{array}$ & $\begin{array}{c}\text { TC/HDL- } \\
\mathbf{C} \text { ratio }\end{array}$ & $\begin{array}{c}\text { TC/LDL- } \\
\mathbf{C} \text { ratio }\end{array}$ & $\begin{array}{c}\text { LDL- } \\
\text { C/HDL-C } \\
\text { ratio }\end{array}$ & $\begin{array}{c}\text { Total } \\
\text { triglyceride } \\
\text { mg/dl }\end{array}$ \\
\hline Normal control & $108.0 \mathrm{a}$ & $66.78 \mathrm{f}$ & $41.22 \mathrm{a}$ & $1.62 \mathrm{a}$ & $2.62 \mathrm{f}$ & $0.62 \mathrm{a}$ & $87.11 \mathrm{a}$ \\
Diabetic control & $235.75 \mathrm{f}$ & $29.62 \mathrm{a}$ & $206.13 \mathrm{f}$ & $7.96 \mathrm{f}$ & $1.14 \mathrm{a}$ & $6.96 \mathrm{f}$ & $186.30 \mathrm{f}$ \\
Group 3 & $143.45 \mathrm{e}$ & $49.98 \mathrm{~b}$ & $93.47 \mathrm{e}$ & $2.87 \mathrm{e}$ & $1.53 \mathrm{~b}$ & $1.87 \mathrm{e}$ & $149.62 \mathrm{e}$ \\
Group 4 & $131.28 \mathrm{~d}$ & $54.14 \mathrm{c}$ & $77.14 \mathrm{~d}$ & $2.42 \mathrm{~d}$ & $1.70 \mathrm{c}$ & $1.42 \mathrm{~d}$ & $125.35 \mathrm{~d}$ \\
Group 5 & $119.13 \mathrm{c}$ & $60.43 \mathrm{~d}$ & $58.7 \mathrm{c}$ & $1.97 \mathrm{c}$ & $2.03 \mathrm{~d}$ & $0.97 \mathrm{c}$ & $117.55 \mathrm{c}$ \\
Group 6 & $110.86 \mathrm{~b}$ & $63.76 \mathrm{e}$ & $47.1 \mathrm{~b}$ & $1.74 \mathrm{~b}$ & $2.35 \mathrm{e}$ & $0.73 \mathrm{~b}$ & $109.68 \mathrm{~b}$ \\
\hline
\end{tabular}

Each value is an average of five determinations

Values followed by the same letter in column are not significantly different at $\mathbf{P} \leq 0.05$

Normal control, Diabetic control, group 3 ... etc. as in Table 1.

Normal values in human should be in the range of:

Total cholesterol (below $200 \mathrm{mg} / \mathrm{dl}$ ) HDL-C (above $45 \mathrm{mg} / \mathrm{dl}$ )

Total triglyceride (50-250 mg/dl) LDL-C (< $160 \mathrm{mg} / \mathrm{dl})$ (Baur, 1995).

It could be seen from the data presented in Table (4) that, diabetic rats fed on basal diet supplemented with raw, soaked and germinated fenugreek flour had a significantly lower serum total cholesterol, total triglyceride and LDL-C compared with diabetic group. In contrary, these groups had a significantly higher level of HDL-C. Meanwhile, normal group fed on basal diet had a significantly lower mean values for TC, TG and LDL-C as well as, higher significant mean value of HDL-C. Data in Table (4) also indicated that, GFF at a level $10 \%$ gave the nearest mean values of TC, TG, LDL-C and HDL-C to the normal group, and recorded a more noticeable effect on hypercholesterolemia of serum total cholesterol and lipoprotein profile followed by GFF at a level $5 \%$ and SFSF $5 \%$ then RFSF came in last. Several differences in the distribution of cholesterol among serum lipoprotein were observed as well. Mean values of TC; LDL-C and TG failed from 235.75, 206.13 and $186.30 \mathrm{mg} / \mathrm{dl}$ in diabetic control to $110.86,47.10$ and $109.68 \mathrm{mg} / \mathrm{dl}$ in rats fed on basal diet supplemented with $10 \%$ GFF, respectively, while HDL-C become higher to reach to 63.76 from $29.62 \mathrm{mg} / \mathrm{dl}$ in the same two treatments.

Numerous reports and earlier experiments also showed similar results with a decrease in level total cholesterol corresponding to a decrease in the LDL fraction (Sharma,1984; Bhat et al., 1985; Sharma et al., 1990; Oakenfull \& Sidhu, 1990; Sauvaire et al., 1991, Sowmya and Rajyalakshmi, 1999 and Coon \& Ernst, 2003). Fenugreek has been shown to bring about a 
hypocholesterolemic effect through different mechanisms. One of such mechanism is increased excretion of fecal bile acid and neutral sterols which led to depletion of cholesterol stores in the liver. Dietary fenugreek stimulates bile formation in the liver and the conversion of cholesterol into bile salts, or the fiber potentially reduce the rate of diffusion towards the absorption mucosal surface.

Sharma (1984); Oakenfull \& Sidhu (1990) and Sauvaire et al. (1991) reported that, cholesterol lowering activity of the glactomannan depends on the D-galactose, D-Mannose ratio. Fenugreek seed contain diosgenin and trigonellin in the form of glycosides. These saponins can form complex with cholesterol in the intestine reducing its absorption, also ingested fenugreek saponins are partially hydrolyzed to diosgenin in the gastrointestinal tract and that diosgenin interferes with cholesterol absorption. Abd El-Salam \& Abd ElMegeid (1998) and Sowmya \& Rajyalakshmi (1999) found that, germinated fenugreek seed showed a significant reduction in the level of serum total cholesterol and LDL fractioin without altering HDL fraction. Bordia et al., (1997) and Hannan et al. (2003) reported that, fenugreek decreased significantly the blood lipids (TC, LDL-C and TG) without affecting the HDL-C.

Total cholesterol is not as useful a predictor of coronary heart disease risk as the relative distribution of cholesterol among lipoprotein e.g. TC/HDL-C and LDL-C/HDL-C ratios (Grundy \& Denke, 1990 and Katan et al., 1994). It has been stated that, the ratio of TC/HDL-C to desirable below 4.0; borderline 4.0-6.0 and high risk of heart disease above 6.0 (Baur, 1995).

The ratios of TC/HDL-C, TC/LDL-C and LDL-C/HDL-C were calculated for all groups of rats fed on different experimental diets and the data are shown in Table (4). The results indicate that, diabetic control (diabetic group) had a ratio of TC/HDL-C (7.96), which was about five folds comparing with normal group and more acceptable to high risk of heart disease. In contrary a lowest ratio was recorded for TC/LDL-C. In relation to LDL-C/HDL-C ratio which accounted a value of 0.62 for the normal rats, this ratio reach to about 11 folds (6.96) in diabetic control. Supplementation of basal diet with all type of fenugreek flour led to improvement the TC/HDLC, TC/LDL-C and LDL-C/HDL-C ratios. GFSF at level $10 \%$ also recorded the best and nearest ratios of TC/HDL-C, TC/LDL-C and LDL-C/HDL-C to the normal control and comparing with other levels of fenugreek types, the mean values were $1.74,2.35$ and 0.73 , respectively. These values were significantly different comparing with that recorded in diabetic control. Abd ElSalam \& Abd El-Megeid, (1998); Marshall, (2000) and Sayed-Ahmed (2002) support our findings.

Effect of raw, soaked and germinated fenugreek flour on liver lipids, phospholipids, cholesterol and triglycerides concentration of diabetic rats:

Table (5) illustrate the mean values of total lipid phospholipids, cholesterol and triglycerides in liver for normal and diabetic groups, as well as the other treatments. The mean values of these parameters were $38.17,1.53$, 1.93 and $1.80 \mathrm{mg} / \mathrm{g}$ liver in normal group, respectively. These mean values increased to $72.59 ; 2.40 ; 3.75$ and $4.29 \mathrm{mg} / \mathrm{g}$ liver of diabetic control group, 
and became high significantly comparing with normal control or other treatments. Supplementation the diet with raw, soaked or germinated fenugreek flour led to significantly reduce in all previous parameter. The highest reduction was observed with 10\% GFF treatment. With the exception of Metwalli (2005), who studied the effect of supplementation of diet with fenugreek flour on hyper-cholesterolemic rats, and indicated that the feeding of hyper-cholesterolemic rats for 6 weeks on basal diet supplemented with $1.5 \%$ of fenugreek seed led to a significant reduction of total cholesterol and total lipids in liver, no available studies were found in literature about the changes in liver content of lipid fractions related to the effect of used raw, soaked or germinated fenugreek flour in diabetic diets of experimental rats. The available studies, were the effect of these factors on blood lipid and the results indicated variable response.

Table (5): Total lipids, phospholipids, cholesterol and triglycerides in liver of normal and diabetic rats fed on different experimental diets for 6 weeks.

\begin{tabular}{|c|c|c|c|c|}
\hline Dietary groups & $\begin{array}{c}\text { Total lipid } \\
\text { mg/g wet liver }\end{array}$ & $\begin{array}{c}\text { Phospholipid } \\
\mathbf{m g} / \mathbf{g} \text { wet liver }\end{array}$ & $\begin{array}{c}\text { Cholesterol } \\
\mathbf{m g} / \mathbf{g} \text { liver }\end{array}$ & $\begin{array}{c}\text { Triglyceride } \\
\mathbf{m g} / \mathbf{g} \text { wet liver }\end{array}$ \\
\hline Normal control & $38.17 \mathrm{a}$ & $1.53 \mathrm{a}$ & $1.93 \mathrm{a}$ & $1.80 \mathrm{a}$ \\
Diabetic control & $72.59 \mathrm{c}$ & $2.40 \mathrm{c}$ & $3.75 \mathrm{e}$ & $4.29 \mathrm{e}$ \\
Group 3 & $51.34 \mathrm{~b}$ & $1.75 \mathrm{~b}$ & $2.68 \mathrm{~d}$ & $3.70 \mathrm{~d}$ \\
Group 4 & $40.60 \mathrm{a}$ & $1.63 \mathrm{ab}$ & $2.34 \mathrm{c}$ & $2.35 \mathrm{c}$ \\
Group 5 & $39.92 \mathrm{a}$ & $1.63 \mathrm{ab}$ & $2.05 \mathrm{~b}$ & $1.98 \mathrm{~b}$ \\
Group 6 & $39.05 \mathrm{a}$ & $1.55 \mathrm{a}$ & $1.96 \mathrm{a}$ & $1.85 \mathrm{a}$ \\
\hline
\end{tabular}

Each value is an average of five determinations

Values followed by the same letter in column are not significantly different at $\mathbf{P} \leq 0.05$ Normal control, Diabetic control, group 3 ... etc. as in Table 1.

Fecal output, fecal lipids and fecal cholesterol excretion in rats fed on different experimental diets:

As shown in Table (6) the mean values of fecal output had no significant differences in most tested groups, but the highest amount $(1.10 \mathrm{~g}$ dry weight/day) and significant result was observed with the group fed on basal diet supplemented with $10 \%$ GFF. However, addition of different types of fenugreek flour to diets caused significantly greater fecal lipids and fecal cholesterol excretion in rats compared with those of normal rats or diabetic control rats. The minimal mean values for fecal lipids and fecal cholesterol excretion were attained in diabetic control rats fed on basal diet (125.17 and $1.58 \mathrm{mg} / \mathrm{g}$ dry weight feces).

Fenugreek seed, being of high saponins content, where able to increase the cholesterol excretion. Generally known, saponins have characteristic cholesterol-binding properties and can form stable foams (Price et al., 1987). The direct binding of dietary saponins with cholesterol and bile acids in the intestinal tract, reducing their absorption in the everted sac (stark \& Madar, 1993). Diet enriched with fenugreek increased both fecal weight and excretion of bile acids and cholesterol (Story et al., 1984 and Bhat et al., 1985). 
Table (6): Fecal output, fecal lipid and fecal cholesterol excretion in normal and diabetic rats fed on different experimental diets for 6 weeks.

\begin{tabular}{|c|c|c|c|}
\hline Dietary groups & $\begin{array}{c}\text { Fecal output } \\
\text { g dry weight/day }\end{array}$ & $\begin{array}{c}\text { Fecal lipid } \\
\text { mg/g dry weight } \\
\text { feces }\end{array}$ & $\begin{array}{c}\text { Fecal cholesterol } \\
\text { mg/g dry weight } \\
\text { feces }\end{array}$ \\
\hline Normal control & $0.87 \mathrm{a}$ & $147.30 \mathrm{~b}$ & $2.96 \mathrm{c}$ \\
Diabetic control & $0.93 \mathrm{ab}$ & $125.17 \mathrm{a}$ & $1.58 \mathrm{a}$ \\
Group 3 & $0.89 \mathrm{a}$ & $157.28 \mathrm{c}$ & $2.85 \mathrm{~b}$ \\
Group 4 & $1.03 \mathrm{bc}$ & $168.71 \mathrm{~d}$ & $3.15 \mathrm{~d}$ \\
Group 5 & $0.96 \mathrm{ab}$ & $172.38 \mathrm{e}$ & $3.78 \mathrm{e}$ \\
Group 6 & $1.10 \mathrm{c}$ & $175.60 \mathrm{f}$ & $4.17 \mathrm{f}$ \\
\hline
\end{tabular}

Each value is an average of five determinations

Values followed by the same letter in column are not significantly different at $\mathbf{P} \leq 0.05$ Normal control, Diabetic control, group 3 ... etc. as in Table 1.

Effect of raw, soaked and germinated fenugreek flour on serum transaminase activities of diabetic rats:

The assay of enzyme levels in the extracellular body fluid such as blood serum, are important aids to the clinical diagnosis and management of a disease. Measurements of the changes in enzyme levels offer more information on the identify of the damaged cell and indicate the degree of injury, than is possible using the other clinico-chemical parameters. Most significant for the development of diagnostic enzymeology were studies on the transaminases, particularly alanine and aspertate transminase. In all liver dysfunction, the alanine and aspertate aminotransferase levels are increased in serum, the extents giving a useful differential index of the type of dysfunction. The activities of key hepatic enzymes; alanine-aminotranferases (ALT), formerly known as glutamic-pyruvic transminase (GPT) and aspertate aminotransferase (AST), formerly known as glutamate-oxaloacetic aminotrnasferase (GOT). In healthy human, the concentration of cellular enzymes in the extracellular fluids are fairly low, ALT and AST ranging between 5-30 IU/L and 8-40 IU/L, respectively (Foster, 1980 and Louz,1997). The enzyme assayed most commonly in liver dysfunction, were measured in rats fed on the basal diet (normal and diabetic control) and diet supplemented with raw, soaked and germinated fenugreek flour and the results are expressed as international unit (IU/L) and are shown in Table (7).

Table (7): Serum alanine aminotransferase (ALT) and aspertate aminotransferase (AST) activities in normal and diabetic rats fed on different experimental diets for 6 weeks.

\begin{tabular}{|c|c|c|c|}
\hline Dietary groups & ALT (IU/L) & AST (IU/L) & GOT/GPT ratio \\
\hline Normal control & $22.7 \mathrm{a}$ & $38.7 \mathrm{a}$ & 1.70 \\
Diabetic control & $258.3 \mathrm{~b}$ & $73.4 \mathrm{~d}$ & 2.90 \\
Group 3 & $23.0 \mathrm{a}$ & $48.5 \mathrm{c}$ & 2.11 \\
Group 4 & $22.5 \mathrm{a}$ & $46.0 \mathrm{bc}$ & 2.04 \\
Group 5 & $22.0 \mathrm{a}$ & $44.2 \mathrm{~b}$ & 2.00 \\
Group 6 & $21.2 \mathrm{a}$ & $39.1 \mathrm{a}$ & 1.84 \\
\hline
\end{tabular}

Each value is an average of five determinations

Values followed by the same letter in column are not significantly different at $P \leq 0.05$ Normal control, Diabetic control, group 3 ... etc. as in Table 1. 
The results in Table (7) showed that, the values of ALT activity reached $21.2 \mathrm{IU} / \mathrm{L}$ for the rats fed on basal diet supplemented with $10 \%$ GFF and $28.3 \mathrm{IU} / \mathrm{L}$ for the diabetic control group fed on basal diet, the activity of normal group was $22.7 \mathrm{IU} / \mathrm{L}$. The results also indicted that, the values measured for ALT activity in all groups and fed on different experimental diets were within the reference values in human and reflecting no volume of cellular damage. On the contrary, the serum AST values recorded for all groups fed on different experimental diets were higher than the reference value in human. Non diabetic rats (normal control) and rats fed on diet supplemented with $10 \%$ GFF gave the nearest values to the reference (38.70 and $39.1 \mathrm{IU} / \mathrm{L}$ ), respectively. Whereas, diabetic rats (diabetic control) recorded higher activity of AST (73.4 IU/L).

From aforementioned obtained results, it should be concluded that, germinated fenugreek flour represent a possible hypoglycemia dietary adjunct and also helped to improve the lipid parameters. So, it is recommended to use germinated fenugreek seed as it is for diabetics, or use its flour for preparing bread or special food for diabetics.

\section{REFERENCES}

Abd El-Hady, S.R.; E.A. Abd El-Rasool and M.A. Salem (2006). Chemical, technological and nutritional evaluation of wheat-fenugreek blends for product balady bread. Proc. $3^{\text {rd }}$ Egypt. \& Syr. Conf. For Agric. \& Food, El-Minia: Nov. 6-9; 3(1): 131-140.

Abd El-Lateef, B.M. and E.M. Salem (1996). The effect of nutritional carob pods flour components on sensory and biological evaluations of rolled biscuits. J. Agric. Sci., Mansoura Univ., 21(4): 1355-1372.

Abd El- Salam, S.M. and Abd El- Megid, A.A. (1998). Biological studies on some legumes as hypoglycemic and hypocholesterolermic agents. Home Economic $5^{\text {th }}$ Scientific conference, 1-21.

Alles, S.M.; M.N. Ross; C.J. Balx; E. Lisdonk; L.P. Zock and G.A. Hautvast (1999). Consumption of fructo-oligosaccharides have favorable affect blood glucose and serum lipid concentration in patients with type 2 diabetes. Am. J. Clin. Nutr., 69(1): 64-69.

Baur, F.J. (1995). Nutritional aspects of oils and fats. In: Food Oils and Fats, Technology, Utilization and Nutrition. Lawson, H. (ed.). Chapman \& Hall, New York, pp. 203-280.

Bhat, G.B.; K. Sambaiah and N. Chandrasekhara (1985). The effect of feeding fenugreek and ginger on bile consumption in the albino rat. Nutr. Rep. Int. 32(5): 1145-51.

Bhattacharya, S.K.; K.S. Satyan and A. Chakarabarti (1997). Effect of trasina, an ayurvedic herbal formulation on pancreatic islet superoxide dismutase activity in hyperglycaemica rats. Ind. J. Exp. Biol.; 35: 297299.

Bialey, C.J. and C. Day (1989). Traditional treatment for diabetes. Diabetes Care, 12: 553-564. 
Bordia, A.; S.K. Verma and K.C. Srivastava (1997). Effect of ginger (Zingiber officinale Rosc) and fenugreek (Trigonella foenum. graecum) on blood lipids, blood sugar and platelet aggregation in patients with coronary artery disease. Postaglandins Leukot Essential. Fatty acids, 56(5): 379-384.

Coon, J.S.T. and E. Ernst (2003). Herbs for serum cholesterol reduction: A systematic review. The Journal of Family Practice, 52(6): 468-478.

David, M.N.; M. James and E.S. Daniel (1997). The epidemiology of cardiovascular diseases in type 2 Diabetes mellitus, how sweet it is ..... or is it? Lancet; 350 (Suppl. 1): 514-519.

El-Khamissy, A. (2005). Studies on biological effects of some diabetes food. Ph.D. Thesis, Faculty of Specific Education. Home Economics, Dept. Tanta Univ.

Eskander, E.F. and H.W. Jun (1995). Hypoglycemic and hyper-insulinemic effect of some Egyptian herbs used for the treatment of diabetes mellitus (type II) in rats. Egypt. J. Pharma. Sci., 36, 1-6.

Esmerino, A.L. (1998). Blood glucose determination in normal and alloxandiabetic rats after administration of local anesthetics containing vasoconstrictors. Braz. Dent. J. 9(1): 33-37.

Folch, J.; M. Lees and G.H. Stanley (1957). A simple method for the isolation and purification of total lipids from animal tissues. J. Biol. Chem. 226: 497-509.

Foster, R.L. (1980). The Nature of Enzymology. Cron. Helm, London. 276312.

Gabr, F.A. (1998). Biochemical studies of some wild plants. Ph.D. Thesis Fac. Agric., Cairo Univ., Egypt.

Grundy, S.M. and M.A. Denke (1990). Dietary influences on serum lipids and lipoproteins. J. Lipid Res., 31: 1149-72.

Hannan, J.M.; B.N. Rokeya; O. Farugquer; N. Nahar; M. Moshihuzzaman; A.K. Khan and L. Ali (2003). Effect of soluble dietary fiber fraction of Trigonella foenum graecum on glycemic, insulinemic, lipidemic and platelet aggregation status of type 2 diabetic model rats. J. Ethnopharmacol. 88(1): 73-77.

Jansen, G.R.; P.E . Kendall and G.M. Jansen (1990). Diet Evaluation: A Guide to Planning a Healthy diet. Academic Press, Inc., Sydney, Tokyo, Boston.

Katan, M.B.; P.L. Zock and R.P. Mensink (1994). Effect of fats and fatty acids on blood lipids in human: An Overview. AM. J. Clin. Nutr., 60: 1017-1022.

Kim, M. and H.K. Shin (1998). The water-soluble of chicory influences serum and liver lipid concentration, cecal short-chain fatty acids concentration and faecal lipid excretion in rats. J. Nutr. 128(1): 17311736.

Kochhar, A. and M. Nagi (2005). Effect of supplementation of traditional medicinal plants on blood glucose in non-insulin depend a pilot study. J. Med. Food., 8(4): 545-549. 
Lehninger, A.L.; D.L. Nelson and M.M. Cox (1993). Principles of Biochemistry: The Molecular Basis of Cell Structure and Function, $2^{\text {nd }}$ ed. Worth Publishers, Inc., New York, USA.

Louz, S.L. (1997). Biological study on soybean product. M.Sc. Thesis, Dept. of Biochemistry, Fac. Of Agric., Cairo vUnvi., Cairo, Egypt.

Lutz, W.J. and W.M. Pardrige (1993). Insulin therapy normalizes glucose transporter mRNA but not immunoreactive transporter protein in streptozotocin diabetic rats. Metabolism, 42(8): 939-944.

Madar, Z.; R. Abdel; S. Samish and J. Arad (1988). Glucose-lowreing effect of fenugreek in non-insulin dependent diabetics. J. Clin. Nutr. 42: 5154.

Marshall, T. (2000). Exploring a fiscal food policy: The case of diet and ischemic disease. Br. Med. J., 320: 301-5.

Mathur, N.K. and G.M. Mathur (2006). Fenugreek gum. Science Tech. Entrepreneur. 1-11.

Metwalli, A.A. (2005). Utilization of some foods for reducing blood cholesterol. Ph.D. Thesis, Fac. Agric. Food Technol. Dept. Tanta Univ. Egypt.

Neeraja, A. and P. Rajyalakshmi (1996). Hypoglycemic effect of processed fenugreek seeds in human. J. Food Sci. Technol., 33(5): 427-430.

Nicolosi, R.J. and I. Ockene (1996). Nutrient bar reducers cholesterol levels. Food Technol., 3: 93-97.

Oakenfull, D. and G.S. Sidhu (1990). Could saponins be a useful treatment for hyperchoelsterolemia. Eur. J. Clin. Nutr. 44: 79-88.

Panlasigui, L.N.; L.M. Panlilio and J.C. Madrid (1995). Glycemic response in normal subjects to five different legumes commonly used in the Philippine. Int. J. Food Sci. Nutr., 46(2): 155.

Pari,L. and R. Saravanan (2004). Antidiabetic effect of diasulin, a herbal drug on blood glucose, plasma insulin and hepatic enzymes of glucose metabolism in hyperglycaemic rats. Diabetes, Obesity and Metabolism, 6: 286-292.

Price, K.R.; I.T. Johnson and G.R. Fenwick (1987). The chemistry and biological significance of saponins in food and feeding stuff. CRC Critical Reviews of Food Science and Nutrition, 26: 27-135.

Raghuram, T.C.; R.D. Sharma; B. Sivakumar and B.K. Sahay (1994). Effect of fenugreek seeds on intravenous glucose disposition in non-insulin dependent diabetic patients. Phyto. Res., 8(2): 83-86.

Reitman, S. and S. Frankel (1957). A colorimetric method for the determination of serum glutamic, oxaloacetic and glutamic pyruvic transaminase. Am. J. Clin. Path., 28: 56-66.

Ribes, G.; Y. Sauvaire and C. DaCosta (1986). Antidiabetic effects of subfractions from fenugreek seeds in diabetic dogs. Pro. Soc. Exp. Biol. Med., 182: 159-66.

Robinson, C.H.; M.R. Lawler; W.L. Chenoweth and A.E. Cawick (1986). Diabetes mellitus, In: Normal and Therapeutic Nutrition. $7^{\text {th }}$ (ed), pp. 504-519. McMillan Publishing Co. New York, U.S.A. 
Rosalyn, Y. and W.A. Bauman (1983). Plasma insulin in health and disease, In: Diabetes mellitus Theory and Practice, M. Ellenbery and H. Rifkin ed., (New York: Excerpta Medica: 119-150).

Safdar, M.; A. Khan and Habibullah (2006). Effect of jaman fruit extract on serum glucose and lipid profile in type 2 diabetic individuals. Pakistan. J. Nutr. 5(6): 573-576.

Saibaba, A.and T.C. Raghuram (1997). Fenugreek. The Wonder seed. Nutrition. 3(2): 21-25.

Sanchez, F.D.; M.M. Game; I. Jimenez and A. Zarzuelo (1994). Hyperglycemic activity of Juniperus "Berries". Plant Med. 60: 197-200.

Sauvaire, Y.; G. Ribes; J.C. Baccou and M.M Loubatieres Mariani (1991). Implication of steroid saponins and sapogenins in the hypocholesterolemic effect of fenugreek. Lipids: 26(3): 191-197.

Sayed-Ahmed, E.F. (2002). Studies on Some Foods for Cordiac disease and Atherosclerosis. Ph.D. Thesis. Dept. Food Technol., Fac. Agric., Moshtohor, Zagazig Univ. (Benha branch), Egypt.

Sharma, R.D. (1984). Hypocholesterolemic activity of fenugreek (Trigonella foenum graecum: An experimental study in rats. Nutr. Rep. Int. 30(1): 221-231.

Sharma, R.D. (1986). Effect of fenugreek seeds and leaves on blood glucose and serum insulin response in human subjects. Nutr. Res. 6: 1353-1364.

Sharma, R.D. and T.C. Raghuram (1990). Hypoglycemic effect of fenugreek seeds in non-insulin dependent diabetic subjects. Nutr. Res. 10: 731 739.

Sharma, R.D.; T.C. Raghuram and N.S. Rao (1990). Effect of fenugreek seeds on blood glucose and serum lipids in type-1 diabetes. Eur. J. Clin. Nutr. 44: 301-306.

Sowmya, P. and P. Rajyalakshmi (1999). Hypocholesterolemic effect of germinated fenugreek seeds in human subjects. Plant Food For Human Nutrition. 53: 359-365.

Stark, A. and Z. Madar (1993). The effect of ethanol extract derived from fenugreek (Trigonella foenum graecum) on bile acid absorption and cholesterol levels in rats. Br. J. Nutr., 69(1): 277-287.

Steel, R.G. and J.H. Torrie (1980). Principles and procedures of statistics. $2^{\text {nd }}$ Ed. McGraw-Hill, New York, USA.

Story, J.A.; S.L. Lepage; M.S. Petro; G.L. West; M.M. Cassidy and G.V. Vohouny (1984). Interactions of alfalfa plant sprout spaonins with cholesterol in vitro and in cholesterol-fed rats. Am. J. Clin. Nutr., 39: 917-929.

WHO, World Health Organization (1980). Expert committee on Diabetes mellitus. Technical Report series 646. Geneva. 


\section{تأثير التغذية على دقيق الحلبة الخـام والمنقوعة والمنبته على سكر الدم وصورة

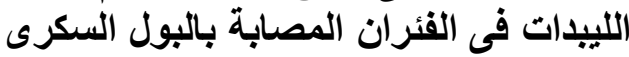

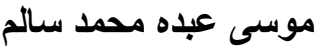 قسم علوم وتكنولوجيا الأغذية ـ كلية الزراعة ـ جامعة طنطا}

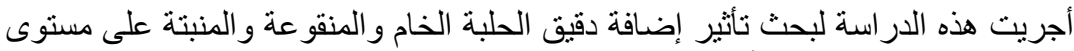

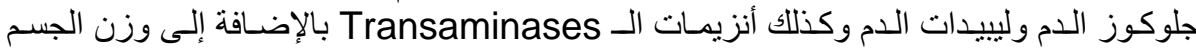

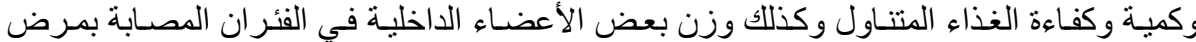

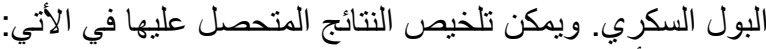

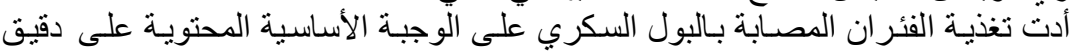

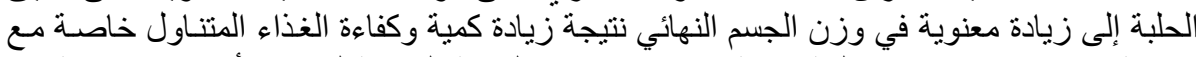

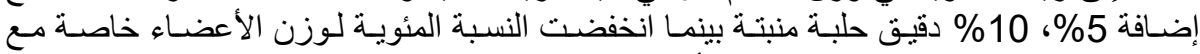

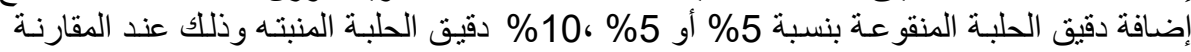
بالقيم المتحصل عليها عند تغذية الفئران المصابة بمرض البول 10بول السكري على الوجبة الأساسية بدون إضـافات.

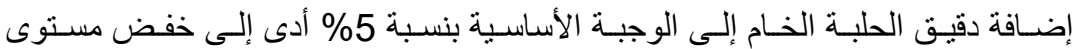

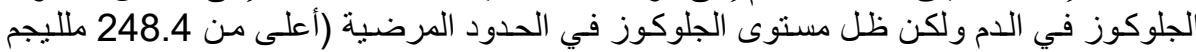

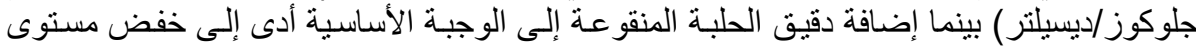

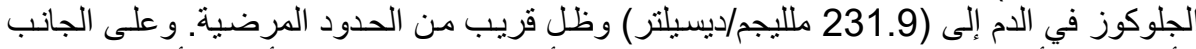

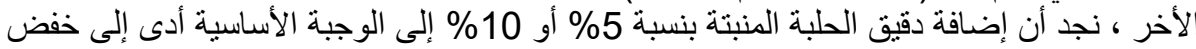

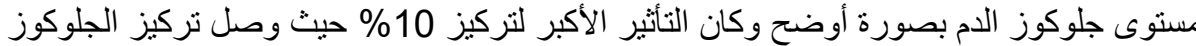
في الدم إلى (209.6 ملإيجم/ديسيلتر) ).

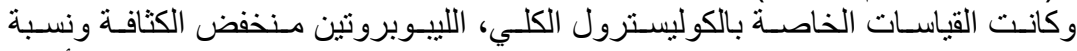

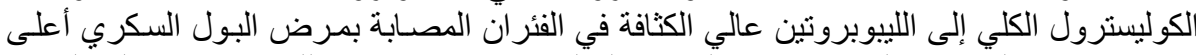

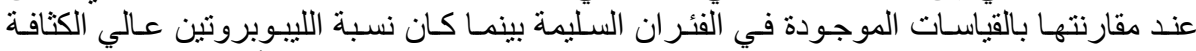

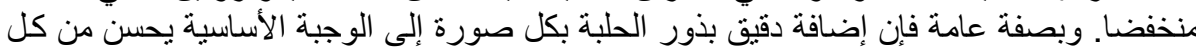
القياسات السابقة ويجعلها في الحدود الطبيعية.

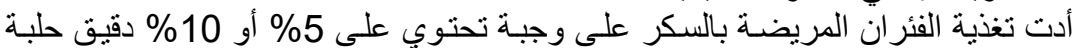

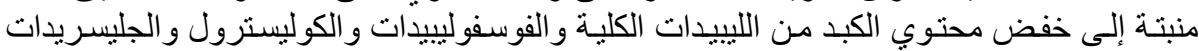

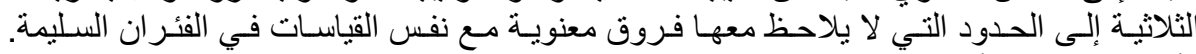

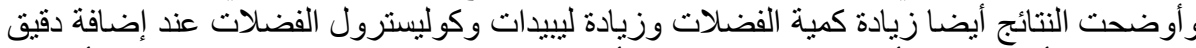

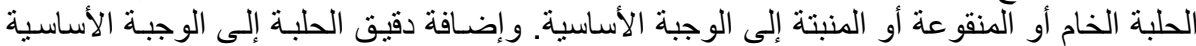

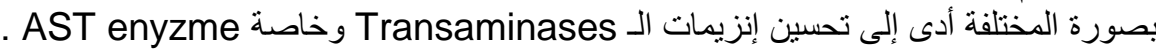
وبناء على ما سبق يمكن التوصية بأن استخدام دقيق الحلبة وخاصـة الحلبة المنبتة بنسبة

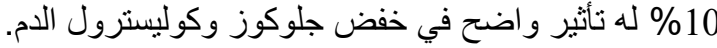

